\title{
The Shaker-Like Potassium Channels of the Mouse Rod Bipolar Cell and Their Contributions to the Membrane Current
}

\author{
David J. Klumpp, ${ }^{1, a}$ Eun Joo Song, ${ }^{2}$ Seisho Ito, ${ }^{1, b}$ Morgan H. Sheng, ${ }^{3, c}$ Lily Y. Jan, ${ }^{3}$ and Lawrence H. Pinto ${ }^{2}$ \\ ${ }^{1}$ Department of Biochemistry, Molecular Biology and Cell Biology and ${ }^{2}$ Department of Neurobiology and Physiology, \\ Northwestern University, Evanston, Illinois 60208 and ${ }^{3}$ Howard Hughes Medical Institute and Department of \\ Physiology, University of California, San Francisco, California 94143
}

\begin{abstract}
RT PCR on mRNA from enzymatically dissociated, isolated bipolar cells showed that these neurons express the Shaker-like $\mathrm{K}^{+}$channels $\mathrm{Kv1.1}, \mathrm{Kv1.2}$, and $\mathrm{Kv1.3.} \mathrm{Immunohisto-}$ chemical localization showed each channel to have a unique subcellular distribution: Kv1.1 immunoreactivity was detected in the dendrites and axons terminal, whereas Kv1.2 and Kv1.3 subunits were localized to the axon and the postsynaptic membrane of the rod ribbon synapse, respectively. Whole-cell patch-clamp recordings indicated that the activation voltage of the delayed rectifier current of the isolated bipolar cell and the inhibitory constants for current blockade by TEA, 4-AP, and $\mathrm{Ba}^{2+}$ were similar to these same properties measured for Kv1.1 expressed in oocytes. However, the TEA and 4-AP Inhlbitory constants for the bipolar cell current differed from the inhibitory constants for Kv1.2 or Kv1.3. These results suggest that the current of the isolated rod bipolar cell is most similar to Kv1.1 but that all three channels may function in the intact retina to allow complex modulation of retinal synaptic signals.
\end{abstract}

[Key words: bipolar cell, potassium channel, RT PCR, ribbon synapse, retina, Shaker]

A wealth of information has accumulated about the structurefunction relationships of $\mathrm{K}^{+}$channels (reviewed in Jan and Jan, 1992; Hoshi and Zagotta, 1993), but relatively little is known about the contributions which specific $\mathrm{K}^{+}$channels make to neuronal membrane currents. Two general approaches are utilized to characterize the contributions of specific $\mathrm{K}^{+}$channels to neuronal currents. In the first approach, $\mathrm{K}^{+}$channel gene expression is altered, and the difference between the wild type and altered

\footnotetext{
Received Nov. 21, 1994; revised Feb. 13, 1995; accepted Feb. 17, 1995.

We are grateful to H. Wang and B. Tempel for help in labeling and photographing Kv1.1 immunoreactivity. We thank Drs. U. Grünert and H. Wässle for useful suggestions for immunohistochemistry and enzymatic dissociation. We also thank A.-M. Chang for excellent management of mouse strains, and we thank J. Burrows and his staff for expert and timely oligonucleotide synthesis. This work was supported by NIH Grants F31MH10238 (D.J.K.) and RO1EY01221 (L.H.P.).

Correspondence should be addressed to Lawrence H. Pinto, Department of Neurobiology and Physiology, Northwestern University, 2-160 Hogan Hall, 2153 North Campus Drive, Evanston, IL 60208.

Present address: Department of Microbiology and Immunology, Northwestern University Medical School, 303 East Chicago Avenue, Chicago, IL 60611.

'Present address: Department of Physiology, Fukushima Medical College, Higari-ga Oka, 960-12 Fukushima, Japan.

cPresent address: Howard Hughes Medical Institute and Department of Neurobiology, Massachusetts General Hospital, Harvard University, Boston, MA 02114.

Copyright (C) 1995 Society for Neuroscience $0270-6474 / 95 / 155004-10 \$ 05.00 / 0$
}

$\mathrm{K}^{+}$currents is compared with the in vitro properties of the specific channel. This approach has been employed to characterize the influence of rapidly inactivating $\mathrm{K}^{+}$channels in Drosophila (see Hardie et al., 1991) and Aplysia (Kaang et al., 1992). In the second approach, the $\mathrm{K}^{+}$channels expressed in a given neuron are identified, and the membrane currents of the neuron are compared with the in vitro properties of the identified channels. Unfortunately, this second approach often suffers from the difficulties of characterizing the $\mathrm{K}^{+}$currents in the same neuron where the channels are identified.

The rod bipolar cell of the mammalian retina has several attributes which suggest that the bipolar cell is an appropriate system for both identifying the expressed $\mathrm{K}^{+}$channels and for recording the neuronal $\mathrm{K}^{+}$currents. First, its morphology and connectivity in the retina are well-known (reviewed in Wässle and Boycott, 1992). Second, the characteristic morphology of bipolar cells is also maintained following isolation by enzymatic dissociation (Kaneko et al., 1989; Karschin and Wässle, 1990), and the identity of rod bipolar cells can be confirmed with antibodies to protein kinase $\mathrm{C} \alpha$ (Negishi et al., 1988; Greferath et al., 1990; Karschin and Wässle, 1990). 'Third, it is possible to record both voltage-gated (Kaneko et al., 1989; Karschin and Wässle, 1990) and ligand-gated currents (Karschin and Wässlc, 1990; Yeh et al., 1990; Yamashita and Wässle, 1991; Feigenspan et al., 1993) from isolated rod bipolar cells. Finally, rod bipolar cells are of a single functional class whose light response is characterized by graded depolarizations within a restricted range of membrane potentials (10-20 mV; Dacheux and Raviola, 1986). Since bipolar cells do not generate action potentials, comparisons of channel and current properties would probably not be complicated by consideration of rapidly inactivating $\mathrm{K}^{+}$channels or accessory subunits (reviewed in Aldrich, 1994). Consistent with these assumptions, the outward voltage-gated currents of mouse (Kaneko et al., 1989) and rat bipolar cells (Karschin and Wässle, 1990) do not have a transient component.

We detected $\mathrm{Kv} 1.1, \mathrm{Kv} 1.2$, and $\mathrm{Kv} 1.3$ subunits in rod bipolar cells. The delayed rectifier of isolated mouse rod bipolar cells had pharmacologic sensitivities which were most similar to the in vitro propertics of Kv1.1 channels. We propose that Kv1.1, $\mathrm{Kv} 1.2$, and $\mathrm{Kv1.3}$ play a role in modulating the physiologic responses of rod bipolar cells in the mouse retina, but that Kv1.2 and Kv1.3 currents are suppressed in the isolated bipolar cell preparation.

\section{Materials and Methods}

Mice. Mice were the C57/B16J strain (alternatively, some animals used in initial physiology experiments were $\mathrm{B} 6 \mathrm{C} 3 \mathrm{~F} 1$ lacking the retinal de- 
generation $(r d)$ phenotype; no difference was observed between bipolar cell membrane currents of $\mathrm{C} 57 / \mathrm{B} 16 \mathrm{~J}$ and $\mathrm{B} 6 \mathrm{C} 3 \mathrm{~F} 1$ ). All mice were adul ranging in age from 3 weeks to 3 months. Mice were maintained on a $12 \mathrm{hr} / 12 \mathrm{hr}$ light/dark cycle, and dissections for all experiments were performed during the light cycle period.

Antiserum preparation. Rabbit anti-Kv1.3 serum was raised against a Kv1.3-specific peptide coupled to a carrier protein as previously described (Sheng et al., 1992). Antiserum was then affinity purified by binding to the Kv1.3-specific peptide. The synthetic Kv1.3 peptide was of the following sequence: GCDRYEPLPPALPAAGEQDC; this sequence corresponds to residues 32-51 near the amino terminus of $\mathrm{Kv} 1.3$ (RCK3; Stühmer et al., 1989). The terminal cysteine residue was then used to couple the peptide to Sulfolink columns (Pierce, Rockford, IL) for affinity purification by standard procedures (Harlow and Lane, 1988). Anti-Kv1.1 serum (Wang et al., 1993) and anti-Kv1.2 (Sheng et al., 1992) were described previously.

Immunoblotting. Retinal membrane proteins were prepared by homogenizing isolated mouse retinas in $10 \mathrm{~mm}$ sodium phosphate $\mathrm{pH} 7.4$, $0.3 \mathrm{~m}$ sucrose, $1 \mathrm{~mm}$ EDTA, $1 \mathrm{~mm}$ phenylmethylsulfonyl fluoride at $4^{\circ} \mathrm{C}$. Debris was pelleted by spinning $1 \mathrm{krpm}$ for $10 \mathrm{~min}$. The supernatant was then spun for $60 \mathrm{~min}$ at $100,000 \times \mathrm{g}$. The resultant pellet was then resuspended for SDS-PAGE. Immunoblotting was performed under standard conditions (Harlow and Lane, 1988), and bands were visualized by ECL detection (Amersham, Arlington Heights, IL).

Immunohistochemistry. Retinas were dissected from eyeballs in Hanks' balanced salts solution and were fixed $15 \mathrm{~min}$. in paraformaldehyde/PBS (retinas used for experiments with anti-Kv1.2 serum were fixed in $2 \%$ paraformaldehyde; all others were fixed in $4 \%$ ). Retinas were then cryoprotected in $10 \%$ sucrose/PBS followed by sinking overnight in $30 \%$ sucrose $/ \mathrm{PBS}$ at $4^{\circ} \mathrm{C}$. After embedding in OCT, $12 \mu \mathrm{m}$ frozen sections were cut, mounted on subbed slides and air-dried. Sections were blocked $15-60 \mathrm{~min}$ at $20^{\circ} \mathrm{C}$ using $1 \%$ bovine serum albumin $1 \%$ Triton X-100, $100 \mathrm{~mm}$ D/ -lysine in PRS. Primary antisera/antibodies were diluted in $1 \%$ bovine serum albumin, $0.5 \%$ Triton X-100 in PBS. Diluted primary antisera were applied to sections, and binding proceeded overnight in a humidificd chamber overnight at $4^{\circ} \mathrm{C}(\mathrm{Kv} 1.2$ immunoreactivity was detected by binding primary antiserum $48 \mathrm{hr}$ at $20^{\circ} \mathrm{C}$ ). Binding of the second primary antibody (in double-label experiments) proceeded for $60 \mathrm{~min}$ at $20^{\circ} \mathrm{C}$. Biotinylated or rhodamine-conjugated secondary antibodies (Amersham, Arlington Heights, IL) were diluted $1: 100$ in PBS and bound $60 \mathrm{~min}$ at $20^{\circ} \mathrm{C}$. Streptavidin.FITC (Amersham, Arlington Heights, IL) was diluted 1:100 in PBS and bound $15 \mathrm{~min}$ at $20^{\circ} \mathrm{C}$. After all binding steps, unbound antibody was removed by washing three times in PBS. All slides were mounted with Choi mount (Dreyfuss et al., 1984) and coverslipped. Immunoreactivity was detected by fluorescence microscopy using the appropriate filter sets.

$P C R$ primers. The following primer pairs were synthesized on an Applied Biosystems DNA synthesizer: L19-U, 5'-GTACTGCCAATGCTCGGATG-3'; L19-D, 5'-TGCCTTCAGCTTGTGGATGT-3'; Kv1.1U, 5'-CAATAGCATAGCCCATTACAGA-3'; Kv1.1-D, 5'-TGCAACAATGCATTGCCAGCA-3'; Kv1.2-U, 5'-AGAATGAGGACATGCATGGT-3'; Kv1.2-D, 5'-TTGCTGGGCATCCTCTGGCT-3', Kv1.3-U, 5'-CAACGTGCCCATCGACATCT-3'; Kv1.3-D, 5'-GGCAGCCTCAACACGTCCT-3'; Kv2.1-U, 5'-TCTACACCACAGCAAGTGCC-3'; and Kv2.1-D, 5'-GTGTGGTTCTCCAGCTTGCAT-3'. These primers permitted amplification of nucleotides $1385-1612$ of Kv1.1 (Tempel et al., 1988), nucleotides 1689-1966 of Kv1.2 (Chandy et al., 1990), nucleotides $1509-1843$ of Kv1.3 (Chandy et al., 1990), nucleotides 21712494 of Kv2.1 (Pak et al., 1991), and nucleotides 248-441 of L19 (Nakamura, 1990).

Isolation of bipolar cells. Two retinas were dissected from eyeballs in Hanks' balanced salts containing $0.5 \mathrm{mM} \mathrm{MgCl}$ and $0.6 \mathrm{mM} \mathrm{CaCl}$ and rinsed twice in the same medium. Retinas were then minced with fine scissors, the tissue was enzymatically and mechanically dissociated by the technique of Karschin and Wässle (1990), which yields cell suspensions highly enriched for intact bipolar cells. The cell suspension was dispersed at low density into a Sylgard-coated (Dow Chemical, Midland, MI) dish which was also treated with dimethyldichlorosilane to prevent cell adhesion.

Identification of rod bipolar cells and rod photoreceptors. Individual bipolar cells were identified on the basis of characteristic morphology (Wässle et al., 1991). Characteristic morphology includes fine dendrites, an ovoid soma, and a single short axon terminating in a lobular appendage. Rod photoreceptors were also identified on the basis of char- acteristic morphology (Ramon y Cajal, 1972) including outer and/or inner segments, and small soma, and occasionally an axon and axon terminal.

RT PCR on individually harvested bipolar cells. Cells were harvested by gently sucking into a patch pipette (broken off to a inner tip diameter of $\sim 15 \mu \mathrm{m}$ ) filled with Hanks' and attached to a Drummond micropipettor; only bipolar cells which were free of nearby cell bodies or debris were harvested to prevent contamination of samples. The bipolar cells (20-50 cells) were vigorously expelled into $5 \mu \mathrm{l}$ of PBS; $100 \mu \mathrm{l}$ of icecold lysis buffer $[10 \mathrm{~mm}$ Tris $\mathrm{HCl} \mathrm{pH} 7.5,140 \mathrm{~mm} \mathrm{NaCl}, 5 \mathrm{~mm} \mathrm{KCl}$, $5 \mathrm{~mm}$ dithiothreitol, 1\% Nonidet P-40, and $40 \mathrm{U}$ RNasin (Promega, Madison, IL)] was added. After $1 \mathrm{~min}$ on ice, cell debris was removed by centrifugation $\left(2 \mathrm{~min}\right.$ at $14 \mathrm{krpm}$ in $4^{\circ} \mathrm{C}$ ), and the supernatant was immediately transferred to $100 \mu l$ of $2 \times$ binding buffer on ice $(20 \mathrm{~mm}$ Tris $\mathrm{HCl} \mathrm{pH} \mathrm{7.5,} 1.0 \mathrm{M} \mathrm{LiCl}, 2 \mathrm{~mm}$ EDTA) containing $0.25 \mathrm{mg}$ of Dynabeads oligo(dT)25 (Dynal Corp., Great Neck, NY). The sample was immediately heated at $65^{\circ} \mathrm{C}$ for $2.5 \mathrm{~min}$. The sample was then cooled quickly on ice, and another $40 \mathrm{U}$ of RNasin was added. After binding mRNA 5 min on ice, the Dynabeads were washed twice with wash buffer containing SDS and then washed four times with wash buffer lacking SDS (wash buffer is $10 \mathrm{~mm}$ Tris $\mathrm{HCl} \mathrm{pH} \mathrm{7.5,50} \mathrm{mM}$ $\mathrm{LiCl}, 1 \mathrm{~mm}$ EDTA, and $\pm 0.2 \%$ SDS). $\mathrm{mRNA}$ was eluted by heating 2 min at $65^{\circ} \mathrm{C}$ in $10 \mathrm{~mm}$ Tris $\mathrm{HCl} \mathrm{pH} \mathrm{7.5.} \mathrm{CDNA} \mathrm{synthesis} \mathrm{and} \mathrm{PCR} \mathrm{were}$ performed using rTth DNA polymerase and accompanying buffers (Perkin Elmer, Norwalk, CT). cDNA synthesis was primed by annealing of the downstream primer at $50^{\circ} \mathrm{C}$ for $2 \mathrm{~min}$ followed by 13 min synthesis at $70^{\circ} \mathrm{C}$. One-half scale reactions $(10 \mu \mathrm{l}$ cDNA synthesis followed by the addition of $40 \mu \mathrm{l}$ PCR mix) were set up according to Perkin Elmer conditions except $10 \mu \mathrm{Ci}$ of $\alpha-{ }^{32} \mathrm{P}-\mathrm{dCTP}$ was included, and $\left[\mathrm{Mg}^{2+}\right]$ was varied to optimize appropriate product formation. Final primer concentration was $0.4 \mu \mathrm{M}$ for each primer. For negative control reactions, polymerase was added only after the addition of PCR mix (containing chelation buffer), and $50 \mu \mathrm{g} / \mathrm{ml}$ RNase A was included. Amplification was obtained through 45 cycles with the following cycling parameters: $94^{\circ} \mathrm{C}$ for $30 \mathrm{sec}, 55^{\circ} \mathrm{C}$ for $60 \mathrm{sec}$, and $70^{\circ} \mathrm{C}$ for $60 \mathrm{sec}$ in an MJ Research PTC 100. Following cycling, samples were incubated $10 \mathrm{~min}$ at $70^{\circ} \mathrm{C}$, 20 min at $95^{\circ} \mathrm{C}$, and were cooled to $4^{\circ} \mathrm{C}$ over $1.5 \mathrm{hr}$ to reduce singlestranded product; $7 \mu 1$ of each reaction was analyzed by electrophoresis through $7.5 \%$ acrylamide. Amplification products were visualized by autoradiography for $60 \mathrm{~min}$ or less at room temperature.

Physiological recording. The recording procedures have been described previously (Kaneko et al., 1989), but in a few cases we employed staining with antibody directed against protein kinase C (Negishi et al., 1988; Karschin and Wässle, 1990) to confirm the identity of bipolar cells used in recording. The outward current was characterized by depolarizations to $+40 \mathrm{mV}$; depolarizations beyond $+40 \mathrm{mV}$ caused the seal to break. For the few cells which withstood depolarization beyond $+40 \mathrm{mV}$, the current amplitude reached a plateau at approximately $+40 \mathrm{mV}$. During characterization of bipolar cell currents, solutions were delivered to the cells with a $\mathrm{U}$-tube device that provided a stream of fluid directed directly toward the cell under study and thus changed the composition of the bathing medium within 3 sec (Suzuki et al., 1990).

\section{Results}

\section{Immunohistochemical identification of $K^{+}$channels}

We generated a polyclonal antiserum against a unique peptide corresponding to amino acids 32-51 at the amino terminus of Kv1.3 (Stuihmer et al., 1989). To determine the specificity of the affinity-purified anti-Kv1.3 serum, immunoblots were performed on retinal membrane protein preparations (Fig. 1). The antiKv1.3 serum recognized a pair of distinct bands of $\sim 70 \mathrm{kDa}$, and these results are consistent with immunoblots of rat brain membrane proteins (M. Sheng, unpublished observations) and probably represent differential glycosylation of the Kv1.3 polypeptide. Both bands were eliminated by preincubating the antiserum with the immunogenic peptide. This suggests that the two major Kv1.3 immunoreactive species in retinal membrane preparations contain the unique Kv1.3 amino acid motif.

We performed indirect immunofluorescence histochemistry (Harlow and Lane, 1988) to localize potassium channel subunits 


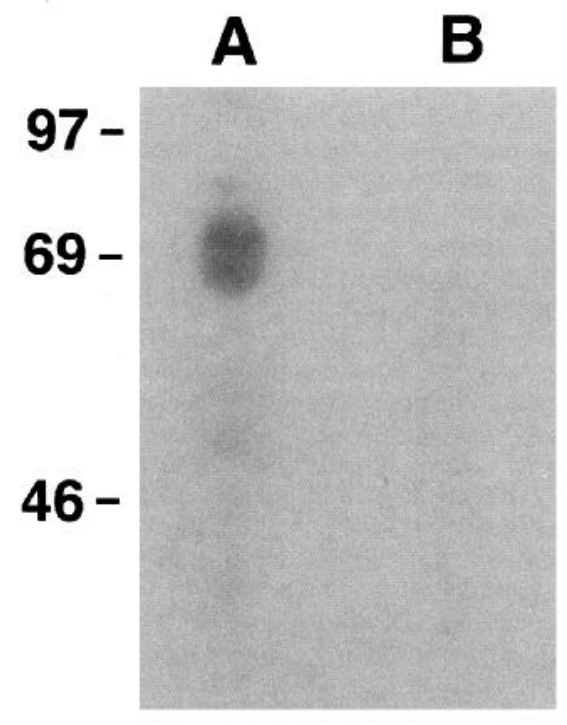

Figure 1. Characterization of anti-Kv1.3 serum. An immunoblot of retinal membrane proteins was probed with Kv1.3 antiserum diluted 1:125, and bands were visualized by chemiluminescence detection (lane A). Preincubation of antiserum with $20 \mu \mathrm{g} / \mathrm{ml}$ immunogenic peptide (lane $B$ ) abolished immunoreactive bands. Each lane contained $8 \mu \mathrm{g}$ of retinal membrane proteins, and numbers indicate the position of Rainbow size standards in kilodaltons (Amersham, Arlington Heights, IL).

within the mouse retina. Retinas were obtained from adult mice and were fixed in paraformaldehyde; $12 \mu \mathrm{m}$ frozen sections were then processed for immunoreactivity. Immunohistochemical results for three different Shaker-like channel subunits are shown in Figure 2.

Anti-Kv1.1 serum (Wang et al., 1993) labeled regions of the inner retina (Fig. $2 A$ ) and both the outer and inner plexiform layers (OPL and IPL, respectively). The IPL labeling had a laminar appearance with the most intense staining appearing within the proximal-most stratum adjacent to the ganglion cell layer.
Immunohistochemical analysis of enzymatically dissociated isolated bipolar cells revealed (Fig. $2 A$, inset) dense staining at their dendrites and axon terminal. This staining of isolated bipolar cells was consistent with that observed in sections because bipolar cell dendrites project into the OPL and the axon terminals of rod bipolar cells lie at the proximal margin of the IPL. Therefore, bipolar cells possess Kv1.1 immunoreactivity.

Using anti-Kv1.2 serum (Sheng et al., 1993), we found a pattern of expression that was very different from that of Kv1.1. Immunoreactivity against $\mathrm{Kv} 1.2$ was diffuse throughout both the OPL and the inner nuclear layer (INL; Fig. $2 B$ ). However, dense staining was observed in radial fibers spanning the INL and IPL. By their location and morphology, these radial fibers appeared to be bipolar cell axons. Kv1.2 immunoreactivity was diffuse and faint in isolated bipolar cells (not shown). This observation raised the possibility that retinal bipolar cells express several types of potassium channels, but independent confirmation of Kv1.2 in bipolar cells was necessary (see below).

We also examined the expression pattern of a third Shakerlike subunit, Kv1.3. In frozen sections, anti-Kv1.3 immúnoreactivity appeared in both plexiform layers (Fig. $2 C$ ). But the staining pattern was, again, distinctly different from that of either $\mathrm{Kv} 1.1$ or Kv1.2. This staining pattern was reduced approximately $30-50 \%$ by preincubation of the antiserum with the immunizing Kv1.3 peptide (not shown); we speculate that the immunoreactivity which was resistant to competition by the peptide reflects a greater affinity of some antibodies for the Kv1.3 epitope in situ. The IPL labeling pattern was not suggestive of Kv1.3 expression in the rod bipolar cell because neither radial fibers nor the innermost IPL were significantly stained. Within the OPL, however, small, densely stained bodies were observed, some of which were up to $2 \mu \mathrm{m}$ in length. The densely stained bodies in the OPL often appeared as small arcs and were distributed across the entire thickness of the OPL. The appearance and location of these arcs was reminiscent of rod ribbon synapses in the mouse retina (Carter-Dawson and LaVail, 1979; Balkema, 1991). As shown for the mGluR6 glutamate receptor
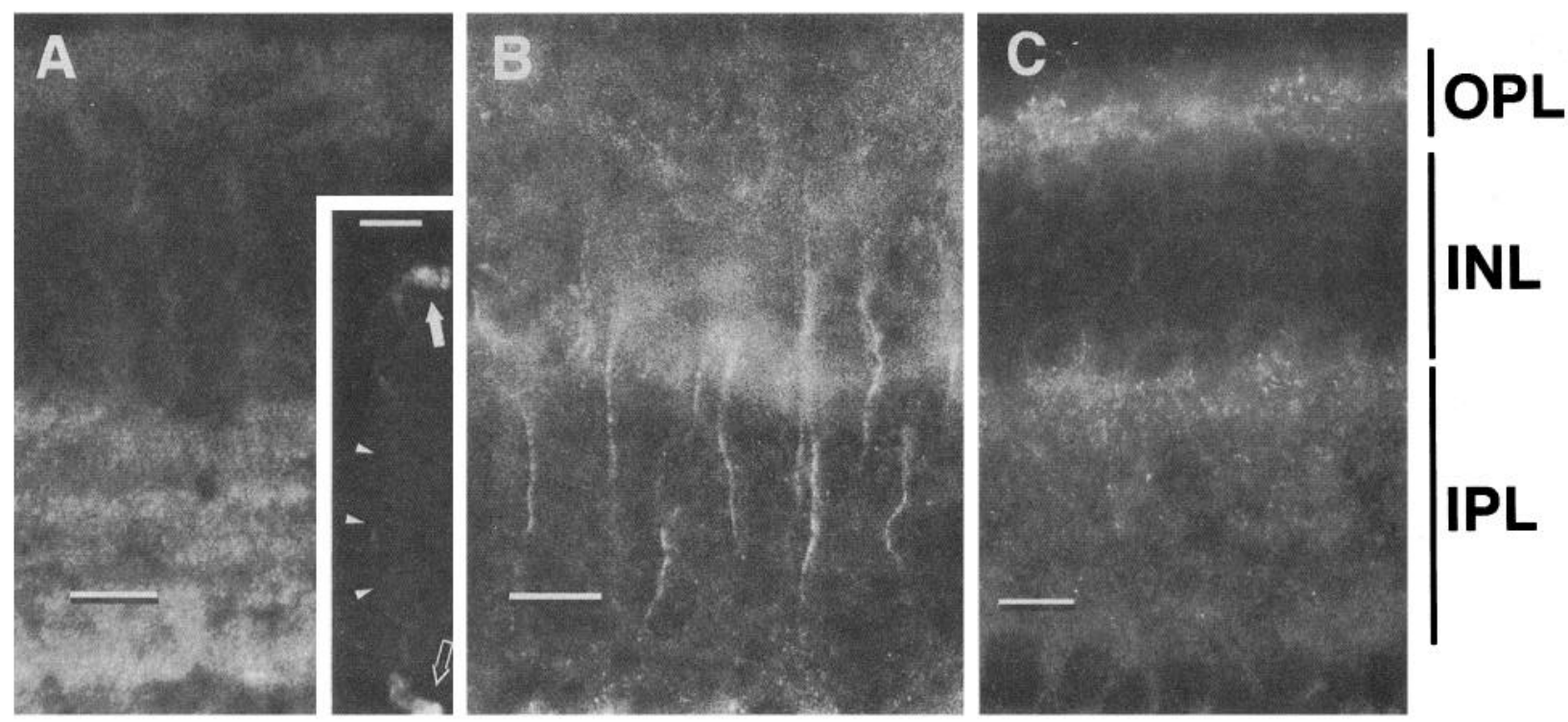

Figure 2. Immunohistochemical localization of $\mathrm{Kv} 1.1(A), \mathrm{Kv} 1.2(B)$, and $\mathrm{Kv} 1.3(C)$ in $12 \mu \mathrm{m}$ frozen sections of mouse retina. In $A$, inset, solid arrow indicates dendrites which appear bundled in this plane of focus; arrowheads indicate path of axon, and open arrow indicates axon terminal. Affinity purified primary antisera were diluted 1:20 (Kv1.1), 1:20 (Kv1.2), and 1:100 (Kv1.3). Scale bars, $10 \mu \mathrm{m}$. 

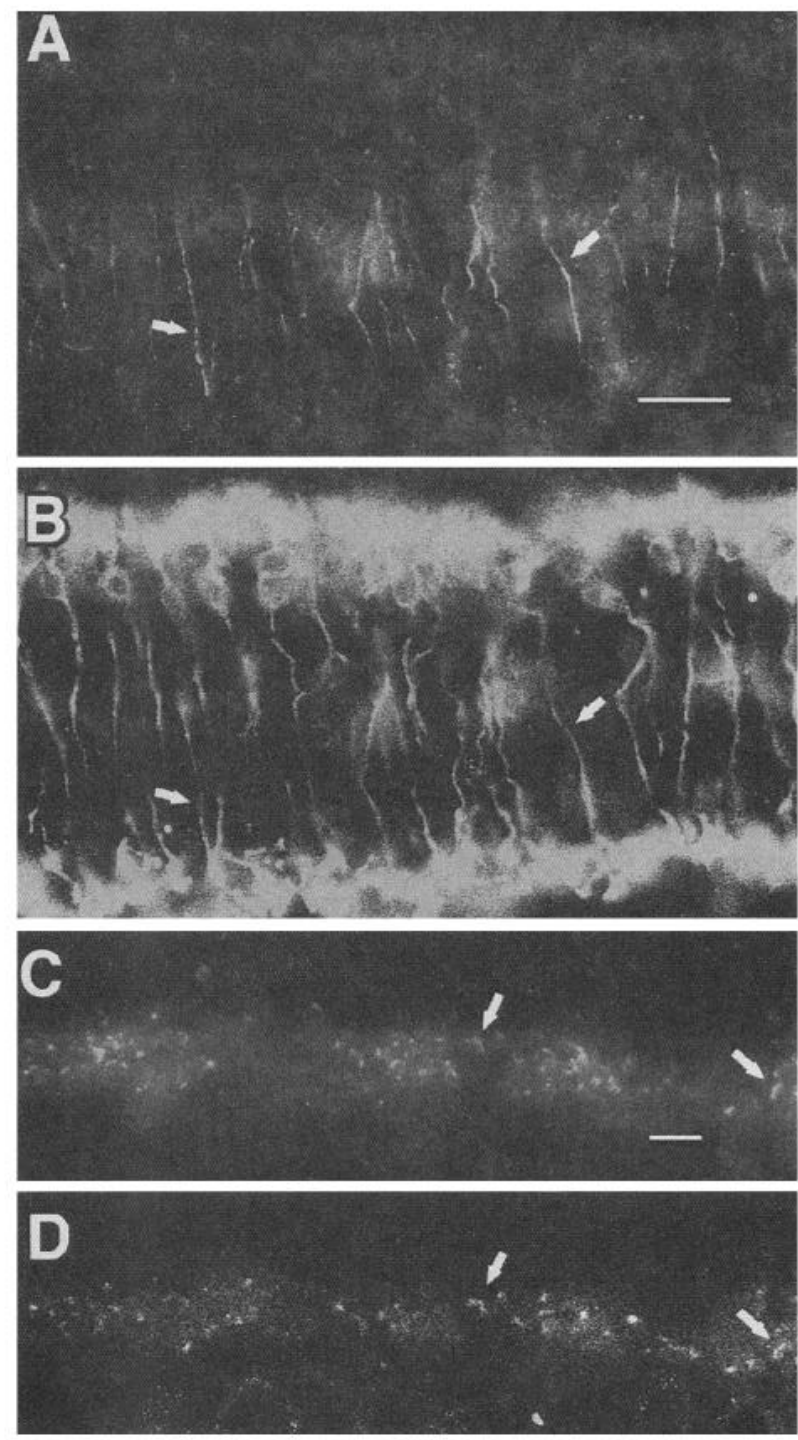

Figure 3. Double-label immunohistochemistry identifies structures labeled by anti-Kv1.2 and anti-Kv1.3 sera. Cryostat sections were stained for Kv1.2 and PKC immunoreactivity $(A, B)$ or for Kvl.3 and B16 immunoreactivity $(C, D) . \mathrm{Kv1}$.2-positive radial fibers $(A)$ corresponded to axons of rod bipolar cells (compare arrows in $A$ and $B$ ) stained for PKC $(B)$. Kv1.3-positive structures $(C)$ in the OPL were closely associated with ribbon synapses (compare arrows in $C$ and $D$ ) labeled by MAb B16 (D). Scale bars: $A$ and $B, 10 \mu \mathrm{m} ; C$ and $D, 5 \mu \mathrm{m}$.

(Nomura et al., 1994), such a localization pattern in the OPL may also indicate expression of Kv1.3 in bipolar cell dendrites. However, we could not determine with immunohistochemical staining of tissue sections whether Kv1.3 subunits were expressed in the pre- or postsynaptic cells synapsing in the OPL. Staining of isolated bipolar cells with the anti-Kv1.3 serum yielded only light, diffuse staining (not shown). Thus, we were uncertain whether Kv1.3 constitutes a third type of Shaker-like subunit in the mouse bipolar cell or is expressed in the rod photoreceptor or horizontal cells.

We performed double-label experiments to identify the structures labeled by the anti-Kv1.2 and anti-Kv1.3 sera. To determine if the radial fibers labeled by anti-Kv1.2 serum were bipolar cell axons (Fig. $3 A, B$ ), frozen sections were labeled with anti-Kv1.2 serum and with antibodies against $\mathrm{PKC}_{\alpha}$ (Amersham,
Arlington Heights, IL), a convenient marker for rod bipolar cells in the retina (Negishi et al., 1988; Greferath et al., 1990; Karschin and Wässle, 1990). PKC antibodies labeled the dendrites, somas, axons, and axon terminals of rod bipolar cells (Fig. $3 B$ ). Kv1.2 antiserum again labeled radial processes (Fig. 3A). Each radial fiber labeled with anti-Kv1.2 corresponded to a bipolar cell axon (compare arrows in Fig. $3 A, B$ ). Conversely, each process labeled with anti-PKC was positive for Kv1.2. We did not find anti-Kv1.2 labeling in processes that were unlabeled by anti-PKC (e.g., cone bipolar axons). Thus, Kv1.2 is expressed in rod bipolar cell axons.

We also used the double-label technique to address the possibility that Kv1.3 subunits were concentrated at ribbon synapses in the OPL. We employed a monoclonal antibody (MAb) specific for ribbon synapses, B16 (Balkema, 1991), to compare the Kv1.3-reactive bodies with ribbon synapses (Fig. 3C,D). The B16 MAb labeled small bodies within the OPL, and these bodies occasionally appeared as arcs (Fig. $3 D$ ). Staining for Kv1.3 was also localized to the OPL where it was concentrated in similar small bodies (Fig. 3C). The ribbon synapses labeled by the B16 antibody were in register with the Kv1.3 bodies in the OPL (compare arrows in Fig. $3 C, D$ ). Although all B16 staining was coincident with Kv1.3 staining, the converse was not true. We suspect that not all ribbon synapses were labeled by the B16 MAb because the epitope recognized by B 16 MAb is sensitive to fixation, and B16 is an IgM which shows low tissue penetration (Balkema, 1991). The structures which stained for Kv1.3 but lacked labeling by B16 may also represent Kv1.3 channels concentrated in horizontal cell processes. Nevertheless, Kv1.3 is expressed in the OPL and is concentrated at rod ribbon synapses. From this experiment, however, it was still unclear whether Kv1.3 was concentrated in the pre- or postsynaptic membrane of the rod ribbon synapse.

\section{Identification of $K^{+}$channels by $R T P C R$}

The inherent limitations of light-microscopic immunohistochemistry made it impossible to determine if the $\mathrm{Kv} 1.3$ labeling in the OPL resides in bipolar cell dendrites or photoreceptor axon terminals. To address the cellular origin of Kv1.3 immunoreactivity in the OPL, and to independently confirm Kv1.1 and Kv1.2 expression in bipolar cells, we employed RT PCR.

Fifty isolated rod bipolar cells were identified on the basis of their characteristic morphology and were harvested. Bipolar cell mRNA was purified, and aliquots were subjected to amplification by RT PCR. Individual reactions were performed using specific primer pairs for Kv1.1 (Tempel et al., 1988), Kv1.2 (Chandy et al., 1990), and Kv1.3 (Chandy et al., 1990). Reactions were also performed using primers for the mouse ribosomal protein L19 (Nakamura, 1990); L19 mRNA is ubiquitously expressed at low levels and provides a convenient positive control for RT PCR (Camp et al., 1991). We performed two types of negative controls. In the first negative control, reverse transcription mix was not added to a reaction until after the addition of PCR mix (the EGTA in the PCR mix chelates the $\mathrm{Mn}^{2+}$ which is required for efficient cDNA synthesis); in addition, RNase was added to the negative control. To conserve the small mRNA sample, only a single reverse transcriptase-minus reaction (using the L19 primers) was amplified as the negative control. We assumed that the purity of the mRNA with respect to L19 reflected a general lack of DNA contamination. Following the successful amplification of $\mathrm{K}^{+}$channel sequences, each primer pair was then used in a "no template" experiment to confirm reagent 
A

\section{$\begin{array}{lllll}\frac{\text { L19 }}{-+} & 1.1 & 1.2 & 1.3 & 2.1\end{array}$}

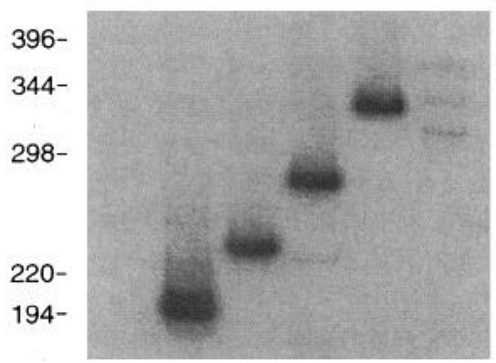

B $\frac{\mathrm{L} 19}{-+} 1.32 .1$

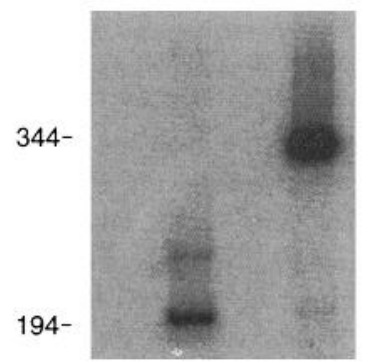

Figure 4. RT PCR detects $\mathrm{K}^{+}$channel mRNAs in rod bipolar cells $(A)$ and rod photoreceptors $(B)$. Rod bipolar cell mRNA was purified from 50 identified cells. For photoreceptors, each reaction contained approximately seven cell equivalents of purified rod photoreceptor mRNA. Target sequences were amplified from mRNA aliquots using the indicated primer pairs. + L19 was a positive control, and - L19 was a negative control where enzyme was added after the addition of EGTA and RNase A. Numbers along left side of each panel indicate position of DNA size markers in base pairs.

purity. The specificity of our RT PCR conditions was tested by amplifying sequences from retinal mRNA (a larger target pool than any one cell type); subsequent cloning and sequencing of PCR products yielded the expected channel sequences.

RT PCR amplified potassium channel sequences from bipolar cell mRNA and from rod photoreceptor mRNA (Fig. 4). L19 primers amplified a sequence which migrated at the predicted size of 194 bp from both bipolar cells (Fig. $4 A$ ) and photoreceptors (Fig. 4B). In contrast, the negative control (L19-) showed no such amplification product from either mRNA preparation. In reactions containing bipolar cell mRNA, the reaction using Kv1.1-specific primers yielded an amplification product which migrated near the predicted size of $228 \mathrm{bp}$, and Kv1.2 and $\mathrm{Kv1.3}$ primer pairs produced amplification products which migrated near the expected sizes of 278 and $335 \mathrm{bp}$, respectively. The reaction performed on bipolar cell mRNA using Kv2.1 primers (a negative control $\mathrm{K}^{+}$channel for which immunohistochemical labeling is not evident in bipolar cell) failed to yield any specific product of the predicted 336 bp size even though the reaction performed with Kv2.1 primers efficiently amplified Kv2.1 sequences from photoreceptors. Finally, in marked contrast to the reaction using bipolar cell mRNA, no Kv1.3 PCR product was generated by RT PCR on rod photoreceptor mRNA (Fig. 4B). These results were obtained in three different preparations of bipolar cells and rod photoreceptors. Since Kv1.3 immunoreactivity was not observed in areas of the inner retina consistent with Kv1.3 subunits in bipolar cell bodies, axons or axon terminals (Fig. 2), Kv1.3 subunits in the bipolar cell are likely localized to the dendrites. Thus, in addition to supporting the immunohistochemical findings of Kv1.1 and Kv1.2 subunits in bipolar cells, the RT PCR results suggest that Kv1.3 immunoreactivity in the OPL resides in bipolar cell dendrites.

Other $\mathrm{K}^{+}$channels probably do not constitute a large fraction of bipolar cell channels. Using primer pairs for other $\mathrm{K}^{+}$channels, we did not detect Kv1.5, Kv1.6, Kv3.1, Kv3.2, Kv3.3, Kv3.4, or Kv4.1 mRNA in bipolar cells (data not shown), although each primer pair efficiently detected expression in retinal mRNA preparations (Klumpp et al., 1995). Likewise, we did not observe immunoreactivity for Kv1.4, Kv2.1, nor Kv4.2 associated with bipolar cells, although extensive immunoreactivity for each of these channels was detected in other retinal neurons (Klumpp et al., 1995). The lack of detectable Kv2.1 sequences in bipolar cell mRNA (Fig. 4) is also consistent with the previous finding that $\mathrm{Kv} 2.1$ immunoreactivity is not associated with bipolar cells in the rat retina (Hwang et al., 1993). Since we did not detect immunoreactivity or mRNA consistent with the expression of other channels, our data suggest that $\mathrm{Kv1} 1.1, \mathrm{Kv} 1.2$, and $\mathrm{Kv} 1.3$ subunits form the major $\mathrm{K}^{+}$channel species of the mouse rod bipolar cell.

\section{Characterization of the bipolar cell delayed rectifier}

Membrane currents were recorded from freshly isolated mouse bipolar cells using the whole-cell version of the patch-clamp technique (Hamill et al., 1981). All cells were obtained by enzymatic dissociation of light-adapted retinas, and all cells used for recording had intact dendrites and axons (inset to Fig. 5A). Depolarization of the bipolar cell membrane from a holding voltage of $-90 \mathrm{mV}$ evoked a slowly activated, outward current (Fig. $5 A)$. The current amplitude became quite large $(0.6-0.8 \mathrm{nA}$ for more than half of the cells) for depolarizations to $30-40 \mathrm{mV}$ (Fig. 5B). The voltage for half-maximal conductance activation of the TEA-sensitive component, $V_{1 / 2}$, was $-8.6 \pm 1.5 \mathrm{mV}$ (SEM; $n=9$ ). The current was largely attenuated by application of $5 \mathrm{~mm}$ tetraethylammonium (TEA), suggesting that the current resulted from a $\mathrm{K}^{+}$conductance. These observations are consistent with earlier reports of an outward current in rodent bipolar cells (Kaneko et al., 1989; Karschin and Wässle, 1990). This large outward current obscured the transient $\mathrm{Ca}^{2+}$ current of the bipolar cell, for the transient current can only be reliably observed when $\mathrm{K}^{+}$current blockers are employed (Kaneko et al., 1989). The outward current showed no inactivation during a 200 msec voltage pulse; therefore, the current does not have a transient component.

We used tail current analysis to study the reversal voltage, $V_{\mathrm{rev}}$, for the slowly activated outward current. The amplitude of the tail current varied monotonically with the test voltage for each value of external $\left[\mathrm{K}^{+}\right]$that was used $(4.9$ to $77 \mathrm{mEq} / \mathrm{liter})$ and changed sign at $V_{\text {rev }}$. The reversal voltage for the current was $-59 \pm 1.0 \mathrm{mV}$ (mean $\pm \mathrm{SEM}$ ) measured in Hanks' solution (Hanks' balanced salts solution); this value was more positive than the expected value of $-73 \mathrm{mV}$, after correction for junction potentials (Fenwick et al., 1982), indicating a slight permeability to other ions. $V_{\text {rev }}$ changed by $47 \mathrm{mV}$ per 10 -fold change in $\left[\mathrm{K}^{+}\right]_{\text {out }}(n=5$ cells; Fig. $6 A)$. Thus, the reversal voltage measured in Hanks' solution and the change in reversal voltage with increasing $\left[\mathrm{K}^{+}\right]_{\text {out }}$ were consistent with $\mathrm{K}^{+}$as the majority charge carrier. Taken together, the voltage activation properties and $\mathrm{K}^{+}$dependence indicate that the outward current of the bipolar cell is a delayed rectifier current, $I_{\mathrm{K}}$.

Occasionally, we recorded from cells where the $V_{1 / 2}$ of the outward current shifted to more negative membrane potentials. This shift occurred within several minutes of breaking the membrane and followed an approximately linear time course (see below). The average shift was $-5.1 \pm 1.8 \mathrm{mV}$ (SEM) in the first minute. This shift may have resulted from alteration of the activation properties of $I_{\mathrm{K}}$ itself or from a decrease in some interfering current, but three observations argue against this latter possibility. First, the magnitude of the $V_{1 / 2}$ shift was not larger for cells with smaller peak current magnitude. Second, a decrease in an interfering current would be expected to cause a change in $V_{\text {rev }}$ parallel to the shift in $V_{1 / 2}$. To test this possibility we alternately and repeatedly measured $V_{\mathrm{rev}}$ and $V_{1 / 2}$ over time 
A

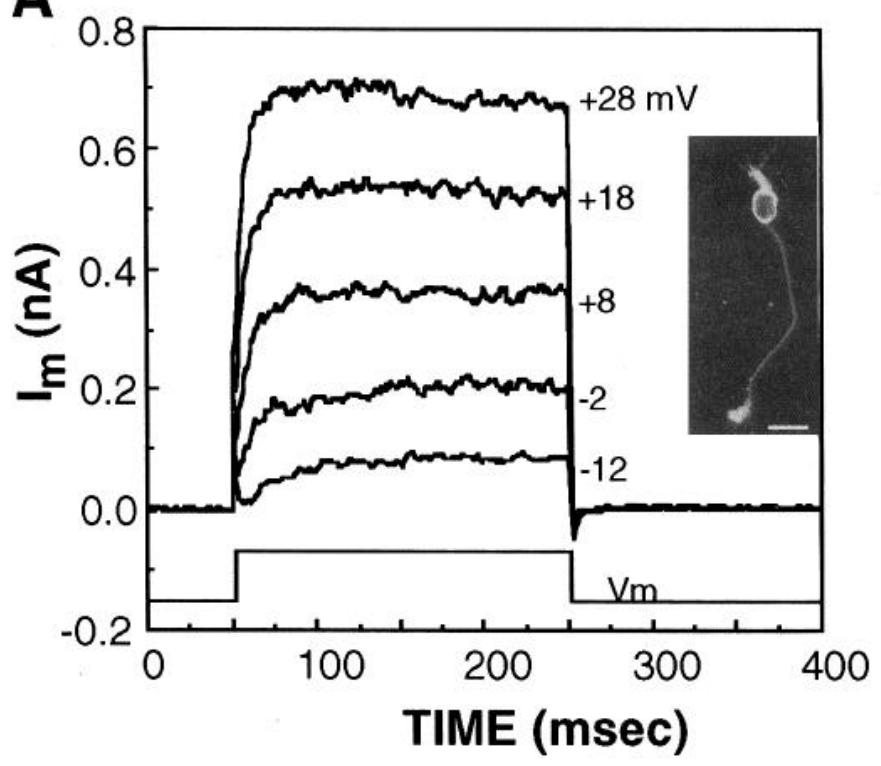

B

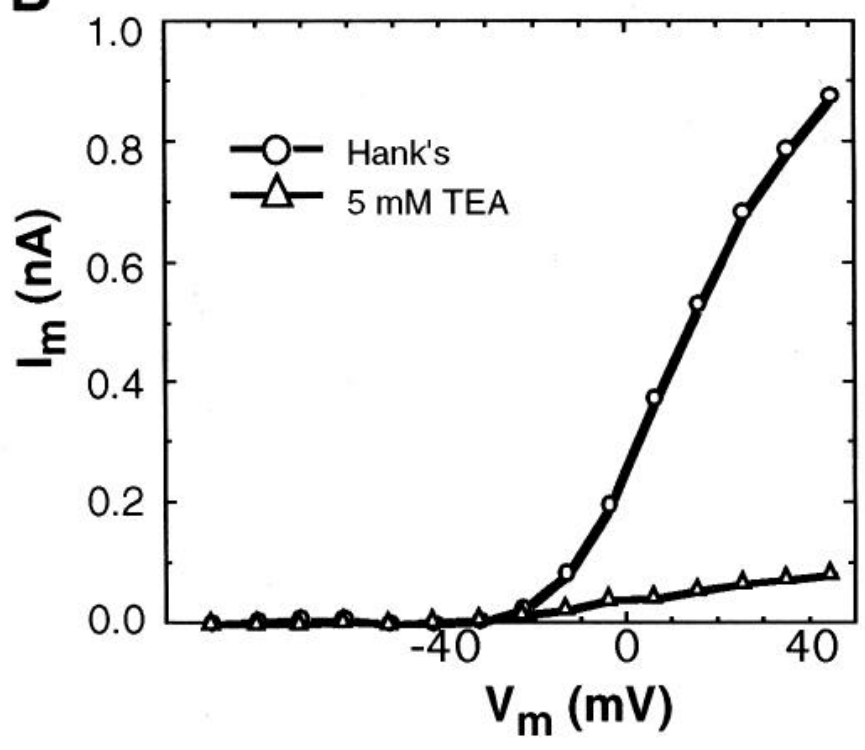

Figure 5. Membrane currents $(A)$ and current-voltage relationship $(B)$ of a mouse retinal bipolar cell studied in Hanks' solution $(A$ and $B$, $O$ ) where the scale bar depicts $10 \mu \mathrm{m}$. A typical rod bipolar cell with PKC immunoreactivity is shown in the inset to A. Numerals in A indicate membrane voltage, and lower record in $A$ is the time course of voltage test pulse. Holding voltage was $-90 \mathrm{mV}$, and $200 \mathrm{msec}$ test pulses were applied. The outward current was attenuated by bathing the cell in Hanks' containing 5 mm TEA $(B, \triangle)$.

in the same cell for two cells (Fig. 6B). We did not observe consistent shifts in $V_{\text {rev }}$ even when the shift in $V_{1 / 2}$ was as large as $-28 \mathrm{mV}$ (Fig. $6 B$ ). Third, we also observed $V_{1 / 2}$ shifts under the following conditions that would be likely to block interfering currents: reduced $\left[\mathrm{Ca}^{2+}\right]_{\text {out }}\left(100 \mu \mathrm{M}\right.$, three cells); $2 \mathrm{mM} \mathrm{Co}^{2+}$ (five cells); reduced $\left[\mathrm{Na}^{+}\right]_{\text {out }}(<1 \mathrm{mM}$, one cell $)$; reduced $\left[\mathrm{Cl}^{-}\right]$ (11 mM, three cells); $50 \mu \mathrm{M}$ niflumic acid (two cells); $10 \mu \mathrm{M}$ nifedipine (one cell) in the bathing solution or $10 \mathrm{~mm}$ BAPTA/1 $\mathrm{mM} \mathrm{Ca}{ }^{2+}$ (three cells) in the patch pipette to quickly buffer intracellular $\mathrm{Ca}^{2+}$ (Neher, 1986). Also, if an interfering current were present, then blocking the interfering current would have affected the peak value of $I_{\mathrm{K}}$, but we did not detect any change in the peak $I_{\mathrm{K}}$ using the above solutions. In addition to the $V_{1 / 2}$ shift, the amplitude of the outward current fell gradually after the beginning of recording; it took about 7 min for this rundown to cause a reduction of the current to $50 \%$ of its original value. Because voltage-gated currents may undergo changes due to intracellular dialysis with pipette solution (Hanck and Sheets, 1992), we characterized the current-voltage relationship for the rod bipolar cell using the perforated patch technique (Horn and
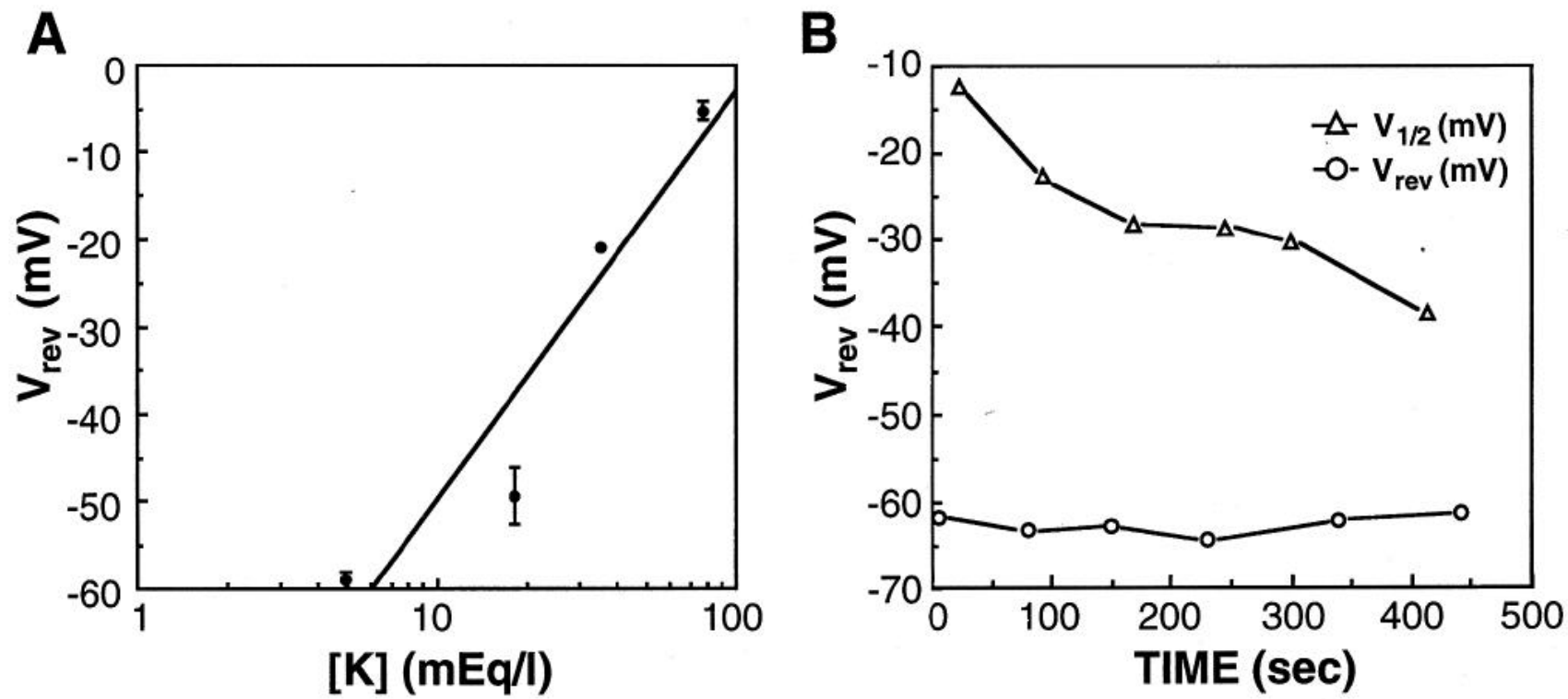

Figure 6. A, The reversal voltage as a function of extracellular $\left[\mathrm{K}^{+}\right]$. Data were averaged from five cells, and $\mathrm{KCl}$ was substituted for $\mathrm{NaCl}$ to vary $\left[\mathrm{K}^{+}\right]$. The line was fitted to these data by the method of least squares and had a slope of $47 \mathrm{mV}$ per 10 -fold change of $\left[\mathrm{K}^{+}\right] . B$, Time courses of the voltage required for half-maximal activation $\left(V_{1 / 2}, \Delta\right)$ of the outward current and of the reversal voltage in the same cell $\left(V_{\text {rev }}, O\right)$ after breaking the seal. 


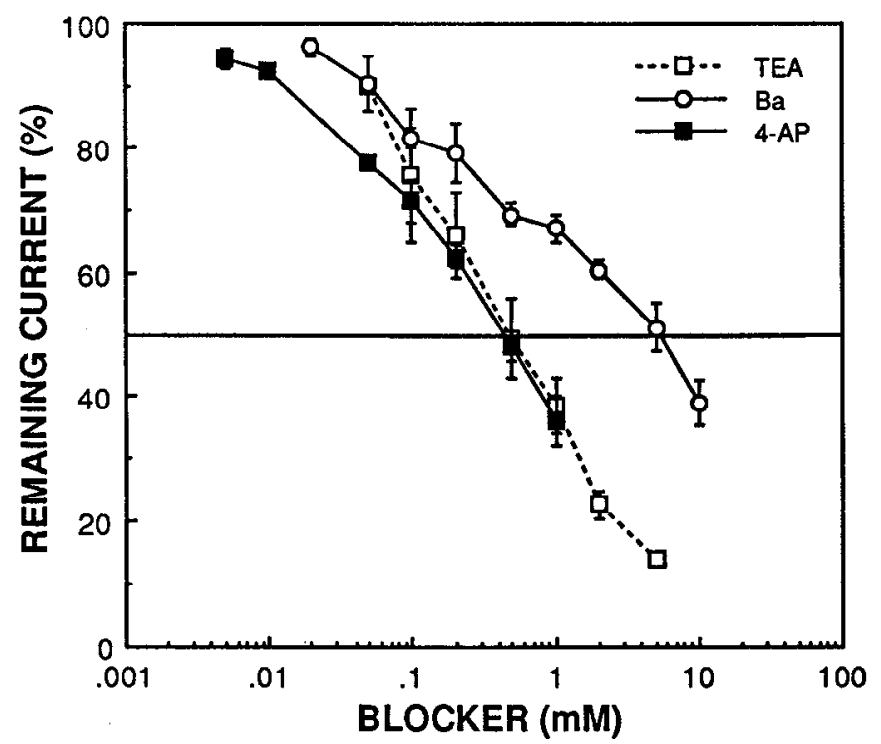

Figure 7. Effect of the concentration of various blockers upon the maximal outward current of the bipolar cell. The percentage of remaining current is plotted against concentration in Hanks' solution for TEA

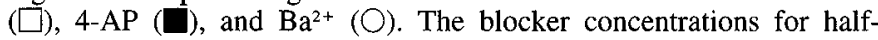
maximal inhibition $\left(\mathrm{IC}_{50}\right.$ ) obtained from this plot were $0.5 \mathrm{mM}$ TEA, $0.4 \mathrm{~mm}$ 4-AP, and $5 \mathrm{~mm} \mathrm{Ba}{ }^{2+}$.

Marty, 1988) with Amphotericin B included in the pipette solution (Rae et al., 1991). No $V_{1 / 2}$ shift or current rundown was observed using the perforated patch configuration. Thus, the rod bipolar cell $I_{\mathrm{K}}$ undergoes a change during intracellular dialysis which may cause current rundown and a shift in $V_{1 / 2}$ over time.

We determined the sensitivity of $I_{\mathrm{K}}$ to pharmacologic blockers of potassium channels. TEA, $\mathrm{Ba}^{2+}$, and 4-aminopyridine were applied individually at various concentrations in Hanks' solu- tion. Peak current was measured before, during, and after washout of the drug, and the current recorded during drug application was corrected for any current rundown which was observed after washout. The percentage of remaining current was plotted as a function of applied blocker concentration (Fig. 7). All three blockers caused significant attenuation of the current when applied in the millimolar concentration range. We determined the concentration which caused half-maximal inhibition of current $\left(\mathrm{IC}_{50}\right)$ for each blocker. The $\mathrm{IC}_{50}$ values were as follows: TEA $(0.5 \pm 0.1 \mathrm{mM}, 11$ cells total $), \mathrm{Ba}^{2+}(5 \pm 1 \mathrm{mM}, 19$ cells total $)$, and 4-aminopyridine $\left(0.4 \pm 0.1 \mathrm{mM}, 19\right.$ cells total). Thus, $I_{\mathrm{K}}$ could be blocked by three agents shown to be effective in blocking the currents of cloned Shaker-like channels expressed in oocytes (Stühmer et al., 1989).

We assessed the contributions that the Shaker-like channels expressed in the rod bipolar cell make to the bipolar cell delayed rectifier current, $I_{\mathrm{K}}$. To do so, we compared the voltage activation and sensitivity to blockers of $I_{\mathrm{K}}$ with these properties for each of the Shaker-like channels of the bipolar cell when these channels are expressed in oocytes (Fig. 8). To compare activation properties, we plotted the activation curves for the bipolar cell $I_{\mathrm{K}}$, mouse Kv1.1 (see Klumpp et al., 1991), ral Kv1.2 (Stühmer et al., 1989), and mouse Kv1.3 (Grissmer et al., 1990) on the same graph (Fig. 8A). Because the conductance that generated $I_{\mathrm{K}}$ shifted after breaking the seal, we plotted representative activation curves both immediately after breaking the seal and 1 min later (thus, the activation curves for individual cells fell within the stippled area of Fig. 8A). Although none of the Shaker-like channel conductances (as characterized in oocytes) is activated within the range of voltages that activate the bipolar cell conductance, $\mathrm{Kv1.1}$ is the channel which is activated at voltages nearest to those that activate $I_{\mathrm{K}}\left(I_{\mathrm{K}}\right.$ is activated at $19 \mathrm{mV}$ more depolarized values).

To overcome the uncertainties associated with comparing ac-
A

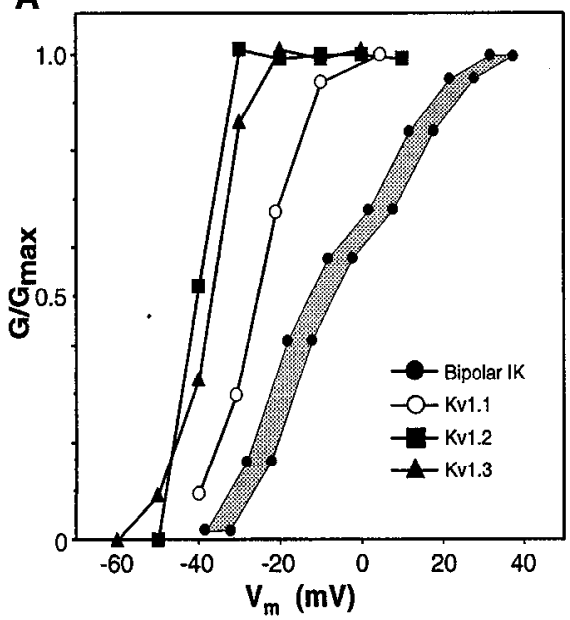

B

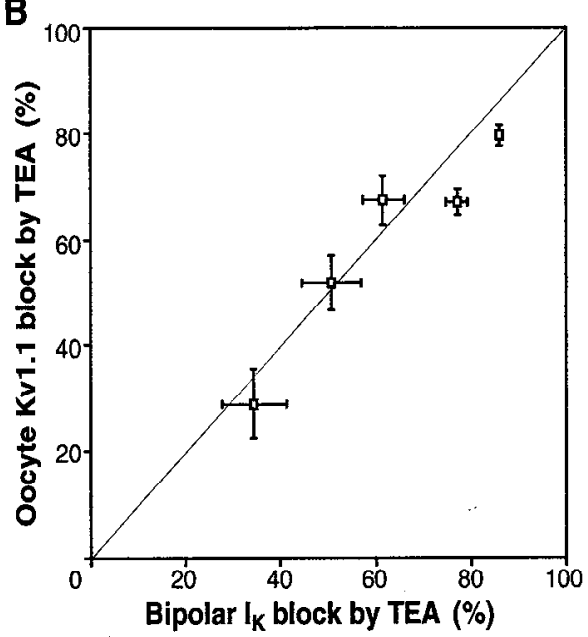

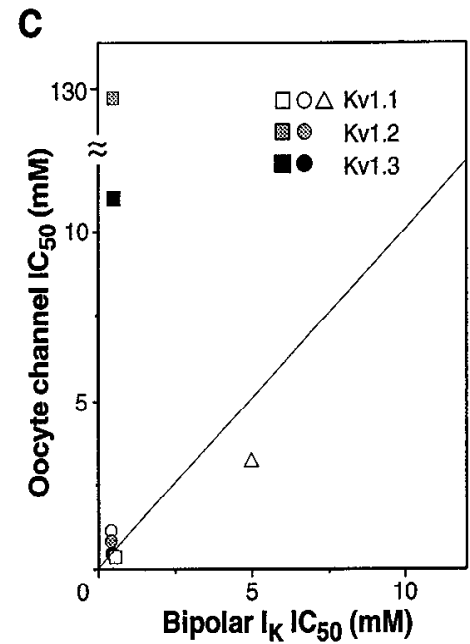

Figure 8. Comparison of bipolar cell $I_{\mathrm{K}}$ with in vitro currents of $\mathrm{Kv1} 1, \mathrm{Kv} 1.2$, and $\mathrm{Kv} 1.3$. $A$, The activation curves $\left(G / G_{\max }\right)$ were plotted as a function of membrane voltage $\left(V_{m}\right)$ for $I_{K}$ and for the currents induced by expression of Kv1.1, Kv1.2, and Kv1.3 in oocytes. The conductance underlying $I_{\mathrm{K}}$ is plotted as a family of conductances (stippled area) to represent the $V_{1 / 2}$ shift observed in some cells; the mean shift ( $-5.1 \mathrm{mV}$ in $60 \mathrm{sec}$ ) was used to determine the more negative boundary of the activation curve. $B$, Comparison of percentage current block by TEA for Kv1.1 in oocytes plotted as a function of percentage current block by TEA bipolar cell for $I_{\mathrm{K}}$. Diagonal line (slope $=1$ ) serves as reference indicating identical blocker sensitivities. TEA concentrations were $0.2,0.5,1.0,2.0$, and $5.0 \mathrm{~mm}$, respectively, for increased current block. $C$, The $\mathrm{IC}_{50}$ values for TEA, 4-AP, and $\mathrm{Ba}^{2+}$ (where available) were plotted for each channel expressed in oocytes as a function of the $\mathrm{IC}_{50}$ values bipolar cell for $I_{\mathrm{K}}$. Open, stippled, and solid symbols represent data for $\mathrm{Kv1.1,} \mathrm{Kv1.2,} \mathrm{and} \mathrm{Kv1.3,} \mathrm{respectively.} \mathrm{Squares,} \mathrm{circles,} \mathrm{and} \mathrm{triangles} \mathrm{represent} \mathrm{data} \mathrm{for} \mathrm{TEA,}$ 4-AP, and $\mathrm{Ba}^{2+}$, respectively. Solid line is the identity lime. Note that the $\mathrm{IC}_{50}$ values for $\mathrm{Kv} 1.2$ and $\mathrm{Kv} 1.3$ do not lie near the identity line, whercas those for Kv1.1 do. 
tivation properties, we compared the blocker sensitivities of the bipolar cell $I_{\mathrm{K}}$ with those of $\mathrm{Kv} 1.1, \mathrm{Kv} 1.2$, and $\mathrm{Kv} 1.3$ expressed in vitro. The apparent inhibitory constant, $\mathrm{IC}_{50}$, for $\mathrm{TEA}$ varies widely among the Shaker-like channels and has a characteristic value for each channel (see Stühmer et al., 1989). The TEAblock of Kv1.1 current in oocytes was compared with the TEAblock of $I_{\mathrm{K}}$ by plotting the percentageage inhibition of Kv1.1 as a function of the percentage inhibition of $I_{K}$ for five concentrations of TEA (Fig. 8B). Both currents showed a similar TEA sensitivity with all points lying about the identity line (slope equal to 1). This similarity extended to the blockers 4-AP and $\mathrm{Ba}^{2+}$ (Fig. 8C). When we plotted the $\mathrm{IC}_{50}$ values for each blocker of $\mathrm{Kvl} .1$ as a function of the $\mathrm{IC}_{50}$ values for the bipolar cell current, the values for each blocker were again similar. However, the sensitivity to TEA of Kv1.2 or Kv1.3 channels was not similar to that of the bipolar cell current. Heteromeric Kv1.1/Kv1.2 and $\mathrm{Kv1} 1 \mathrm{~K} / \mathrm{Kv} 1.3$ channels exhibit TEA $\mathrm{IC}_{50}$ values at least fourto fivefold greater than those reported here for $I_{K}$ (Christie et al., 1990), although sensitivities of heteromeric channels to blockers may vary with the subunit composition (e.g., Kavanaugh et al, 1992). Although we did not detect currents with the known TEA sensitivities of heteromeric channels, we cannot exclude the possibility that such channels underlie a minor fraction $I_{\mathrm{K}}$ in the rod bipolar cell. Alternatively, such channels may be inactivated in our preparation but constitute a significant fraction of functional bipolar cell channels in situ (see below). However, taken together, our comparisons of the voltage and blocker sensitivities suggest that Kv1.1 channels may underlie the majority of the delayed rectifier current in freshly isolated bipolar cells.

\section{Discussion}

$K^{+}$channels expressed in the bipolar cell

We used a combination of immunohistochemistry and RT PCR on individually identified cells to identify potassium channels expressed in mouse rod bipolar cells. We found three potassium channel subunits, Kv1.1, Kv1.2, and Kv1.3, were expressed in the rod bipolar cell. Each subunit is distributed within the bipolar cell in a unique subcellular distribution. The distribution patterns overlap only slightly (Kv1.1 and Kv1.3 in dendrites) suggesting that much of the bipolar cell $\mathrm{K}^{+}$current may flow through homomeric channels.

The results of indirect immunofluorescence, performed on both frozen sections and enzymatically dissociated cells, are consistent with the presence of Kv1.1 channel subunits in bipolar cell dendrites and axon terminals. We found no evidence for radial fibers labeled by anti-Kv1.1 serum in tissue sections (such as those observed using anti-Kv1.2 serum), so Kv1.1 subunits appear to be largely excluded from the axon. Previous studies have shown that some $\mathrm{K}^{+}$channel subunits are consistently found in a single subcellular domain (Sheng et al., 1992), whereas other subunits show a variable subcellular distribution depending upon cellular context (Hwang et al., 1993; Sheng et al., 1993, 1994; Wang et al., 1993). However, since Kv1.1 subunits are apparently localized to both bipolar cell dendrites and axon terminals, this may represent the first report of a $\mathrm{K}^{+}$channel which is targeted to the opposite poles of the same neuron.

$\mathrm{Kv} 1.2$ immunoreactivity was detected in rod bipolar cell axons, and these results were corroborated by the detection of Kv1.2 mRNA in individually identified bipolar cells using RT PCR (Fig. 4). This corroboration was important because the $\mathrm{Kv} 1.2$ antiserum used in this study detects a family of proteins on immunoblots of rat brain membrane proteins (probably dif- ferentially glycosylated $\mathrm{Kv} 1.2$ as well as a cross-reacting $68 \mathrm{kDa}$ protein; Sheng et al., 1994). In spite of this, in rat brain all immunohistochemical localization of Kv1.2 is consistent with RNA localization determined by in situ hybridization (Tsaur et al., 1992; Sheng et al., 1994). Thus, we find Kv1.2 subunits are expressed in bipolar cells of the mouse, where they are restricted to axons. The absence of other detectable Shaker-like subunits in the bipolar axons suggests that the subcellular localization of Kv1.2 subunits may be directed by intrinsic or cell-specific factors in addition to a "dominant partner/passive follower" mechanism (Sheng et al., 1994).

Kv1.3 immunoreactivity was found in the OPL where Kv1.3 subunits were concentrated at ribbon synapses in the OPL. Using RT PCR we detected Kv1.3 mRNA in purified bipolar cell mRNA, but Kv1.3 mRNA was not detected in mRNA of the presynaptic cell, the rod photoreceptor. Since we did not observe immunoreactivity consistent with Kv1.3 subunits in bipolar cell bodies, axons or axon termini, Kv1.3 expression in bipolar cell dendrites must account for the labeling pattern observed in the OPL. A similar distribution was recently reported for the bipolar cell-specific glutamate receptor, mGluR6 (Nomura et al., 1994). Thus, Kv1.3 subunits are localized to the dendrites of bipolar cells, where they are concentrated at sites postsynaptic to the rod ribbon synapse.

\section{The potassium current of the isolated mouse rod bipolar cell}

We characterized the outward current of isolated mouse rod bipolar cells. The current was activated by depolarization, with a $V_{1 / 2}$ of $-8.6 \mathrm{mV}$, was carried largely by $\mathrm{K}^{+}$ions, and showed no inactivation during $200 \mathrm{msec}$ depolarizations. Thus, the outward current of mouse rod bipolar cells is characteristic of a delayed rectifier, $I_{K}$. The $V_{1 / 2}$ we measured for the bipolar cell current was more positive than the reported resting voltage for bipolar cells in the retina (Werblin and Dowling, 1969; Toyoda, 1973; Kaneko and Shimazaki, 1976) and thus appears appropriate for stabilizing the membrane voltage of a cell that depolarizes in response to light. The $I_{\mathrm{K}}$ showed a gradual rundown and, occasionally, a shift in $V_{1 / 2}$ caused by intracellular dialysis. The bipolar cell $I_{\mathrm{K}}$ exhibited sensitivity to TEA, 4-AP and $\mathrm{Ba}^{2+}$ in the millimolar concentration range, consistent with the expression of a delayed rectifier (Hille, 1992).

The bipolar cells of certain fish and amphibia express a more complex set of outward currents than those reported here for the rod bipolar cell of the mouse. For certain bipolar cells of the white bass, a prominent A-current is found (Lasater, 1988); in the goldfish retina, a Ca-dependent $\mathrm{K}^{+}$current has been reported (Kaneko and Tachibana, 1985); and in both enzymatically dissociated cells and in a slice preparation of the axolotl, a voltagedependent $\mathrm{K}^{+}$current with a transient component is found (Tessier-Lavigne et al., 1988). The differences between these results and our results for the mouse rod bipolar are probably due to differences between species and/or differences in the subtypes of bipolar cells recorded because rat rod bipolar cells also exhibit an outward current with properties that are similar to those reported here for the mouse (Karschin and Wässle, 1990).

We did not observe currents with the characteristics expected for Kv1.2 and Kv1.3 in isolated rod bipolar cells, but Kv1.2 and $\mathrm{Kv} 1.3$ channels probably play a role in bipolar cell physiology in the intact retina. This suggests that the isolated bipolar cell preparation may not completely model the bipolar cell in situ despite many studies documenting intact voltage- and ligandgated responses in the isolated preparation (see introductory sec- 
tion). The absence of Kv1.2 and Kv1.3 currents in our isolated cell preparation was probably not due to loss of dendrites or axons because these structures remained intact during the isolation procedure (see inset to Fig. 5A). Nevertheless, it is possible that damage by papain or other aspects of the isolation procedure contributed to the absence of functional Kvl.2 and Kv1.3 channels.

Alternatively, the absence of Kv1.2 and Kv1.3 currents in isolated rod bipolar cells may reflect intrinsic properties of bipolar cell physiology. The circuitry of the rod/bipolar cell synapse responds such that the light-induced cessation of glutamate release from the photoreceptor results in depolarization of the bipolar cell (reviewed in Copenhagen, 1991). By depriving the bipolar cell of synaptic inputs, the isolation procedure mimics a sustained rod light response (no glutamate). The absence of glutamate may cause prolonged depolarization of the bipolar cell. This prolonged depolarization could activate $I_{\mathrm{Ca}}$ of the mouse bipolar cell (Kaneko et al., 1989). Although the bipolar cell $I_{\mathrm{Ca}}$ flows through transient channels, such transient $\mathrm{Ca}^{2+}$ influxes are now known to be capable of stimulating calcium effector pathways (Lieberman and Mody, 1994)-especially over the short distances within the bipolar cell (Roberts, 1994). Interestingly, Kv1.2 and Kv1.3 currents are largely or totally suppressed by $\mathrm{Ca}$-dependent mechanisms, but $\mathrm{Kv} 1.1$ currents are only suppressed about 50\% (Hoger et al., 1991; Guillemare et al., 1992; Aiyar et al., 1993). It may be that Kvl.2 and Kvl.3 channels are largely inhibited in the isolated bipolar cell by $\mathrm{Ca}$-dependent pathways whereas Kvl.1 currents are only partially affected. Such conditions would lead to a delayed rectifier with the properties we observed: a TEA sensitivity which approximated that of Kv1.1 channels but not the sensitivily of $\mathrm{Kv1.2}$ or $\mathrm{Kv} 1.3$ channels.

\section{Physiological significance of Shaker-like channels in the rod bipolar cell}

The presence of Shaker-like channels in the dendrites, soma, axon, and axon terminal of the rod bipolar cell suggests that these channels may regulate diverse processes such as postsynaptic responsiveness, signal integration and/or neurotransmitter release. The differential subcellular distribution of each subunit type also suggests that each channel plays a unique role in contributing to the total bipolar cell response. The rod bipolar cell rests near $-30 \mathrm{mV}$ (Werblin and Dowling, 1969; Toyoda, 1973; Kaneko and Shimazaki, 1976). Since Kv1.2 displays a $V_{1 / 2}$ of $-35 \mathrm{mV}$ (Stühmer et al., 1989) and mouse Kv1.3 is half-maximally activated at $-35 \mathrm{mV}$ (Grissmer et al., 1990), the bipolar cell structures containing these channels may be locally hyperpolarized in the intact retina. Given their location, this would permit Kv1.3 channels to oppose the depolarization induced by cGMP-gated channel opening (reviewed in Copenhagen, 1991), and Kv1.2 channels could electrically isolate the soma from the axon terminal.

The rod bipolar cell has contributed to our understanding of how potassium channels behave in an isolated cell preparation and how the activity of these channels must differ in situ. These results support the general notion that a neuron expresses several different $\mathrm{K}^{+}$channel subunits, and the unique subcellular localization of identified subunits in the bipolar cell suggests different and diverse roles for each channel in contributing to the physiological responses in vivo. In the rod bipolar cell, future experiments should address the impact of iontophoretic application of $\mathrm{K}^{+}$channel blockers to specific regions of the cell while record- ing membrane currents in a slice preparation. The mammalian bipolar cell thus provides a rich system for future studies on the contributions of specific potassium channel molecules to neuronal function.

\section{References}

Aiyar J, Grissmer S, Chandy KG (1993) Full-length and truncated $\mathrm{Kv} 1.3 \mathrm{~K}^{+}$channels are modulated by 5 -HT1c receptor activation and independently by PKC. American J Physiol (Lond) 265:C1571C1578.

Aldrich RW (1994) New channel subunits are a turn-off. Curr Biol $4: 839-840$.

Balkema GW (1991) A synaptic antigen (B16) is localized in retinal synaptic ribbons. J Comp Neurol 312:573-583.

Camp TA, Rahal JO, Mayo KE (1991) Regulation of ovarian gonadotropin receptor mRNAs. Mol Endocrinol 5:1-13.

Carter-Dawson LD, LaVail MM (1979) Rods and cones in the mouse retina: structural analysis using light and electron microscopy. $\mathbf{J}$ Comp Neurol 188:245-262.

Chandy KG, Williams CB, Spencer RB, Aguilar BA, Ghanshani S, Temple BL, Gutman GA (1990) A family of three mouse potassium channel genes with intronless coding regions. Science 247:973-975.

Christie MJ, North RA, Osborne PB, Douglass J, Adelman JP (1990) Heteropolymeric potassium channels expressed in Xenopus oocytes from cloned subunits. Neuron 2:405-411.

Copehagen DR (1991) Synaptic transmission in the retina. Curr Opinion Neurobiol 1:258-262.

Dacheux RF, Raviola E (1986) The rod pathway in the rabbit retina: a depolarizing bipolar and amacrine cell. J Neurosci 6:331-345.

Dreyfuss G, Choi YD, Adams SA (1984) Characterization of heterogeneous nuclear RNA-protein complexes in vivo with monoclonal antibodies. Mol Cell Biol 6:1104-1114.

Feigenspan A, Wässle H, Bormann J (1993) Pharmacology of GABA receptor $\mathrm{Cl}^{-}$channel in rat retinal bipolar cells. Nature 361:159-162.

Fenwick E, Marty A, Neher E (1982) Sodium and calcium channels in bovine chromaffin cells. J Physiol (Lond) 331:599-634.

Greferath U, Grünert U, Wässle H (1990) Rod bipolar cells in the mammalian retina show protein kinase $\mathrm{C}$-like immunoreactivity. $\mathrm{J}$ Comp Neurol 301:433-442.

Grissmer S, Dethlefs B, Wasmuth JJ, Goldin AL, Gutman GA, Cahalan MD, Chandy KG (1990) Expression and chromosonal localization of a lymphocyte $\mathrm{K}^{+}$channel gene. Proc Natl Acad Sci USA 87:94119415 .

Guillemare E, Honore E, Pradier L, Lesage F, Schweitz H, Attali B, Barhanin J, Lazdunski M (1992) Effects of the level of mRNA expression on biophysical properties, sensitivity to neurotoxins, and regulation of the brain delayed-rectifier $\mathrm{K}^{+}$channel Kv1.2. Biochemistry $31: 12463-12468$.

Hamill OP, Marty A, Neher E, Sakmann B, Sigworth F (1981) Improved patch-clamp techniques for high-resolution current recording from cells and cell-free membrane patches. Pfluegers Arch 391:85100.

Hanck DA, Sheets MF (1992) Time-dependent changes in kinetics of $\mathrm{Na}^{+}$current in single canine cardiac Purkinje cells. Am J Physiol 262:HI 197-HI207.

Hardie RC, Voss D, Pongs O, Laughlin SB (1991) Novel potassium channels encoded by the Shaker locus in Drosophila photoreceptors. Neuron 6:477-486.

Harlow E, Lane DP (1988) Antibodies: a laboratory manual. Cold Spring Harbor, NY: Cold Spring Harbor I aboratory.

Hille B (1992) Ionic channels of excitable membranes. Sunderland, MA: Sinauer.

Hoger JH, Walter AE, Vance D, Yu L, Lester HA, Davidson N (1991) Modulation of a cloned mouse brain potassium channel. Neuron 6:227-236.

Horn R, Marty A (1988) Muscarinic activation of ionic currents measured by a new whole-cell recording method. J Gen Physiol 92:145159.

Hoshi T, Zagotta WN (1993) Recent advances in the understanding of potassium channel function. Curr Opinions Neurobiol 3:283-290.

Hwang PM, Cunningham AM, Peng YW, Snyder SH (1993) CDRK1 and DRK $1 \mathrm{~K}^{+}$channels have contrasting localizations in sensory systems. Neuroscience 55:613-620. 
Jan LY, Jan YN (1992) Structural elements involved in specific $\mathrm{K}^{+}$ channel functions. Annu Rev Physiol 54:537-555.

Kaang B-K, Pfaffinger PJ, Grant SGN, Kandel ER, Furukawa Y (1992) Overexpression of an Aplysia Shaker $\mathrm{K}^{+}$channel gene modifies the electrical properties and synaptic efficacy of identified Aplysia neurons. Proc Natl Acad Sci USA 89:1133-1137.

Kaneko A, Shimazaki H (1976) Synaptic transmission from photoreceptors to bipolar and horizontal cells in the carp retina. Cold Spring Harbor Symp Quant Biol 40:537-546.

Kaneko A, Tachibana M (1985) A voltage-clamp analysis of membrane currents in solitary bipolar cells dissociated from Carassius auratus. J Physiol (Lond) 358:131-152.

Kaneko A, Pinto LH, Tachibana M (1989) Transient calcium current of retinal bipolar cells of the mouse. J Physiol (Lond) 410:613-629.

Karschin A, Wässle H (1990) Voltage- and transmitter-gated currents in isolated rod bipolar cells of rat retina. J Neurophysiol 63:860-876.

Klumpp DJ, Farber DB, Bowes C, Song E-J, Pinto LH (1991) The potassium channel MBK1 is expressed in the mouse retina. Cell Mol Neurobiol 11:611-622.

Klumpp DJ, Song E-J, Pinto LH (1995) Identification and localization of $\mathrm{K}^{+}$channels in the mouse retina. Vis Neurosci 12: in press.

Lasater EM (1988) Membrane currents of retinal bipolar cells in culture. J Neurophysiol 60:1460-1480.

Lieberman DL, Mody I (1994) Regulation of NMDA channel function by endogenous $\mathrm{Ca}^{2+}$-dependent phosphatase. Nature 369:235-239.

Nakamura T, Onno M, Mariage-Samson R, Hillova J, Hill M (1990) Nucleotide sequence of mouse L19 ribosomal protein cDNA isolated in screening with tre oncogene probes. DNA Cell Biol 9:697-703.

Negishi K, Kato S, Teranishi T (1988) Dopamine cells and rod bipolar cells contain protein kinase C-like immunoreactivity in some vertebrate retinas. Neurosci Lett 94:242-257.

Neher E (1986) Concentration profiles of intracellular calcium in the presence of diffusible chelator. Exp Brain Res 14:80-96.

Nomura A, Shigemoto R, Nakamura Y, Okamoto N, Mizuno N, Nakanishi S (1994) Developmentally regulated postsynaptic localization of a metabotropic glutamate receptor in rat rod bipolar cells. Cell 77: 361-369.

Pak MD, Baker K, Covarrubias M, Butler A, Ratcliffe A, Salkoff L (1991) $\mathrm{mShal}$, a subfamily of A-type $\mathrm{K}^{+}$channel cloned from mammalian brain. Proc Natl Acad Sci USA 88:4386-4390.

Rae J, Cooper K, Gates G, Watsky M (1991) Low access resistance perforated patch recordings using amphotericin B. J Neurosci Methods $37: 15-26$.

Ramon y Cajal S (1972) The structure of the retina. Springfield, IL: Thomas.
Roberts WM (1994) Localization of calcium signals by a mobile calcium buffer in frog saccular hair cells. J Neurosci 14:3246-3262.

Sheng M, 'I'saur M-L, Jan YN, Jan LY (1992) Subcellular segregation of two A-type $\mathrm{K}^{+}$channel proteins in rat central neurons. Neuron 9:271-284.

Sheng M, Liao YJ, Jan YN, Jan LY (1993) Presynaptic A-current based on heteromultimeric $\mathrm{K}^{+}$channels detected in vivo. Nature 365:7275.

Sheng M, Tsuar M-L, Jan YN, Jan LY (1994) Contrasting subcellular localization of the $\mathrm{Kv} 1.2 \mathrm{~K}^{+}$channel subunit in different neurons of rat brain. I Neurosci 14:2408-2417.

Stühmer W, Ruppersberg JP, Schroeter KH, Sakmann B, Stocker M, Giese KP, Perschke A, Baumann A, Pongs O (1989) Molecular basis of functional diversity of voltage-gated potassium channels in mammalian brain. EMBO J 8:3235-3244.

Suzuki S, Tachibana M, Kaneko A (1989) Effects of glycine and $\mathrm{G} \wedge \mathrm{B} \Lambda$ on isolated bipolar cells of the mouse retina. J Physiol (Lond) 421:645-662.

Takahashi JS, Pinto LH, Hotz Vitaterna M (1994) Forward and reverse genetic approaches to behavior in the mouse. Science 264:17241733.

Tempel BL, Jan YN, Jan LY (1988) Cloning of a probable potassium channel gene from Inouse brain. Nature 332:837-839.

Tessier-Lavigne M, Attwell D, Mobbs P, Wilson M (1988) Membrane currents in retinal bipolar cells of the axolotl. J Gen Physiol 91:4972.

Toyoda J-I (1973) Membrane resistance changes underlying the bipolar cell response in the carp retina. Vision Res 13:283-294.

Tsaur M-L, Sheng M, Lowenstein DH, Jan YN, Jan LY (1992) Differential expression of $\mathrm{K}^{+}$channel mRNAs in the rat brain and downregulation in the hippocampus following seizures. Neuron 8:10551067.

Wang H, Kunkel DD, Martin TM, Schwartzkroin PA, Tempel BL (1993) Heteromultimeric $\mathrm{K}^{+}$channels in terminal and juxtaparanodal regions of neurons. Nature 365:75-79.

Wässle H, Boycott BB (1992) Functional architecture of the mammalian retina. Physiol Rev 71:447-480.

Wässle H, Yamashita M, Greferath U, Grünert U, Müller F (1991) The rod bipolar cell of the mammalian retina. Visual Neurosci 7:99-112.

Werblin FS, Dowling JE (1969) Organization of the retina of the mudpuppy, Necturus maculosus. II. Intracellular recording. J Neurophysiol 32:339-355.

Yamashita M, Wässle H (1991) Responses of rod bipolar cells isolated from the rat retina to the glutamate agonist 2-amino-4-phosphonobutyric acid (APB). J Neurosci 11:2372-2382.

Ych HH, Lec MB, Chcun JE (1990) Propertics of GABA-activated whole-cell currents in bipolar cells of the rat retina. Visual Neurosci $4: 349-357$. 